\title{
Anatomical Structure of Vegetative and Generative Organs of Silybum marianum (L.) Gaertn. (Fam. Asteraceae)
}

\author{
B. A. Nigmatullaev ${ }^{1}$, G. M. Duschanova ${ }^{2}$, B. A. Abdurahmonov ${ }^{1}$, G. B. Sotimov ${ }^{1}$ \\ ${ }^{1}$ Institute of the Chemistry of Plant Substances AS RUz, Tashkent, Uzbekistan \\ ${ }^{2}$ Institute of Botany AS RUz, Tashkent, Uzbekistan \\ Email: baxtiyor.nigmatullayev@mail.ru
}

How to cite this paper: Nigmatullaev, B.A., Duschanova, G.M., Abdurahmonov, B.A. and Sotimov, G.B. (2019) Anatomical Structure of Vegetative and Generative Organs of Silybum marianum (L.) Gaertn. (Fam. Asteraceae). American Journal of Plant Sciences, 10, 38-43.

https://doi.org/10.4236/ajps.2019.101004

Received: November 19, 2018

Accepted: January 6, 2019

Published: January 9, 2019

Copyright $\odot 2019$ by author(s) and Scientific Research Publishing Inc. This work is licensed under the Creative Commons Attribution International License (CC BY 4.0).

http://creativecommons.org/licenses/by/4.0/

\begin{abstract}
The article provides information about the anatomical structure of the vegetative and generative organs grown in Tashkent conditions, and reveals the structural features: a mesomorphic leaf, a dorsi-central mesophyll type characteristic of dicotyledonous plants; stem beam type. A comparative analysis of the anatomical structure showed that the seed coat has a general plan of the structure with other members of the family Asteraceae.
\end{abstract}

\section{Keywords}

Silybum marianum, Anatomical Structure, Leaf, Fruit, Adaptation

\section{Introduction}

Silybum marianum (L.) Gaertn. is an annual or biennial prickly plant of the Aster family (Asteraceae), widely distributed in Europe, North Africa and America, Australia, the Caucasus, the Middle and Central Asia. Its height reaches 1.5 - 2 meters; the leaves are large, bright green and shiny. The whole plate of the leaf is covered with white spots and ridges of veins, from which a milky sap is released during the break. The edges of the leaves and veins of the collateral side have yellowish spines, as a result of which the plant in Russia is called "thistle" or "sharply-colored"; in English-speaking countries "milk thiestl" "lady s thistle" is "milk or female thistle"; seed fruit with a tuft.

Flowering and fruiting in May and June, the plant mainly grows in wheat crops, along irrigation canals and aryks, in weedy places [1].

Milk thistle is Silybum marianum, a folk remedy for liver cirrhosis, acute and chronic hepatitis, jaundice, bile duct diseases, and colic. The main active ingre- 
dients are flavonolignans (silybin, silicristin, silydianin) contained in the fruit. In addition, they contain saponins, fatty oil, proteins, vitamin K, resins, mucus, tyramine, histamine, as well as macro and microelements.

Other organs in the aerial parts of the plant also contain flavonoids and flavolignans, which exhibit hepatoprotective activity and they may well be pharmaceutical raw materials for the production of biologically active compounds (BAC).

Materials and Methods: To study the anatomical structure of Silybum marianum (L.) Gaertn., samples were taken from the above-ground organs growing on the experimental plot of the Institute of Chemistry of Plant Substances. The leaf, stem and fruit of the plant are fixed in 700-ethanol for anatomical examination. The structure of the leaf and its epidermis were studied on a dermal and transverse section. The epidermis is described by the method of S.F. Zakharevich [2]. The structure of the base of the stem and fruits is studied in cross sections. The preparations were prepared by hand, painted with methylene blue, safranin, and followed by gluing with glycerin-gelatin [3]. Microphotography was performed with a digital camera (brand A 2300 "Canon").

\section{Result and Discussion}

Leaf: The leaves are thin, light green, spotty, on both sides very short pubescent, lateral lobes ovoid triangular, prickly-toothed along the edge. On the paradermal section, the outlines of the epidermal cells are rectilinearly rounded, the projection is polygonal. The cells of the adaxial epidermis are larger than the abaxial ones. Trichomes are absent.

The leaves are amphiphomatic. The stomata are transverse to the longitudinal axis of the sheet. The stomata form is oval and rounded. The mouth is most abundant on the abaxial side, less on the adaxial side. The stomata closing cells on both sides of the leaf are almost the same length. Stomach not immersed. The stomata type is an anomocytic (Figure 1).

The leaf mesophyll in cross section is dorsi-central, characteristic of dicotyledonous plants. The epidermis is represented by one row of cells with a thin layer of the cuticle. The cells of the upper epidermis are larger than the lower ones. Palisade parenchyma large cell consists of 2 rows. Spongy parenchyma is round, small-celled, consists of 7 - 8 rows with small cavities. Crystals of glycosides and starch grains are found in the cells of the palisade and spongy parenchyma. The lateral conductive beams are numerous, with 3 - 4 small vessels (Figure 1).

The main leaf vein is issued on the abaxial side. Under the upper epidermis there is a loose 2 - 4 row collenchyme. Under the lower epidermis in the ribs are groups of collenchyme cells. Chlorophyllan parenchyma is represented by $2-3$ rows of cells in the lower side of the leaf. The rest of the vein is occupied by the main parenchyma, in which 5 conductive beams are immersed; the parenchyma cells are thin-walled, multi-faceted. Conductive beams open bicollateral, consist of 3 large and 2 small. Phloem beams located on 2 sides beam. Xylem vessels are thick-walled, elongated. Their walls are thickened in the form of spirals or rings. 


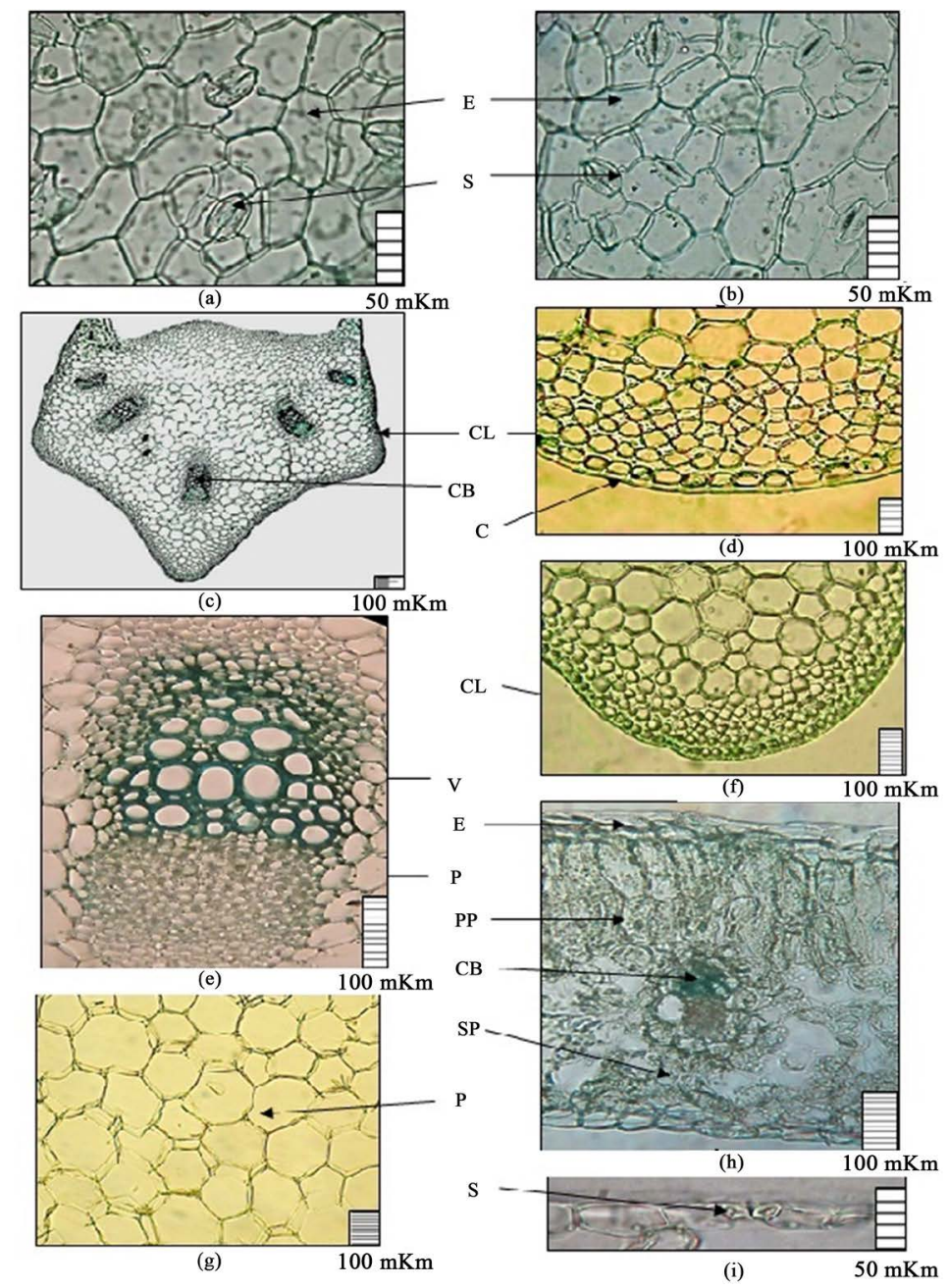

Figure 1. Silybum marianum leaf structure: (a) adaxial epidermis; (b) abaxial epidermis. (c)-(f) detail of a general view; (g)-(f) is a loose collenchyme; (h) bicollateral PP; (i) parenchymal cell; and immersed stomata. Legend: SP spongy parenchyma, C cuticle, CL collenchyma, $\mathrm{P}$ parenchyma, PP palisade parenchyma, CB conductive bunch, Vvessel, $\mathrm{S}$ stomata, $\mathrm{P}$ phloem, E epidermis.

\section{Stem}

The stem base on the cross section is ribbed, beam-like structure. Primary bark is preserved throughout the rest of the growing season. The epidermis is single row, consists of oval cells, pubescent with simple single-cell hairs. The outer wall of the cells is significantly thickened. The primary cortex is $7-8$ rows, the cells of the 2 outer rows are small, almost round and oval. Loose collenchyma located under the epidermis in the ribs, consists of 7 - 8 rows of cells. Chlorenchyma is represented by 3 - 4 rows of parenchymal cells, which are located behind the collenchyme and between areas of the collenchyme (in the valley). In the central cylinder there are numerous separate conductive beams. Open bicollateral conductive beams, large and small. Xylem vessels are thick-walled, of various shapes and thickening of the walls of blood vessels spiral.

The core is extensive, represented by large rounded oval cells, among which 
there are hydrocytic cells. The core occupies most of the stem cross-section (Figure 2).

L.G. Muradyan [4] studied the microstructure of the seed of 10 species of the genus Jurinea Cass. (this. Asteraceae) and identified a number of common characteristics. A correlation of traits is in the structures of the pericarp and sperm.

U.N. Zhapakova, G.F. Begbaeva [5] studied the structure of fruits, seeds and leaf organs of the species Senecio subdentatus LDB (family Asteraceae) and identified various xeromorphic and halomorphic features and adaptive strategy of the species to the habitat.

Analysis of the literature data showed that $S$. marianum fruits have a high level of polymorphism in the color of the seed coat: from cream to bright brown or black shells [6].

Fruit: In cross section, a pericarp seed consists of several layers: the covering cuticle; heterogeneous epidermal layer of exocarpium, which from the base of the seed is represented by thick-walled weakly porous cells, and from the side of the cuticle turns into palisade-like elongated thick-walled cells; pigment layer-one row of thin-walled, loose cells; a layer of fibrous cells of the mesocarp, consisting of 1 - 10 rows of cells; crumbled endocarp cells painted yellow or orange and containing calcium oxalate crystals (Figure 3).

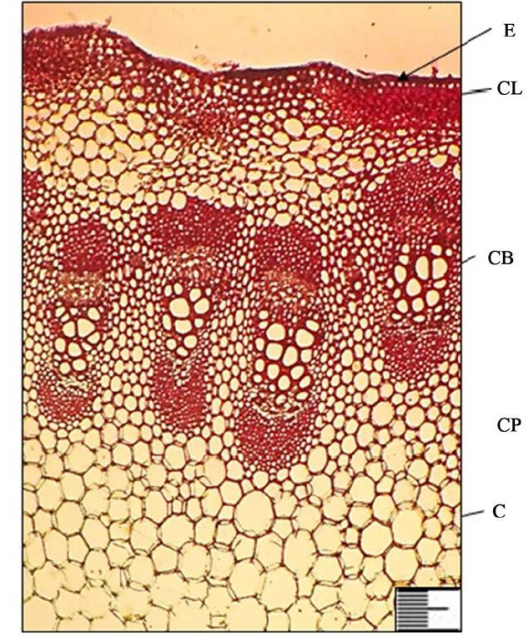

(a)

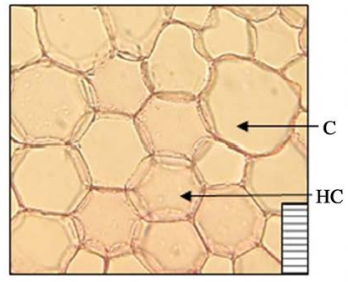

(d)
$100 \mathrm{MKM}$

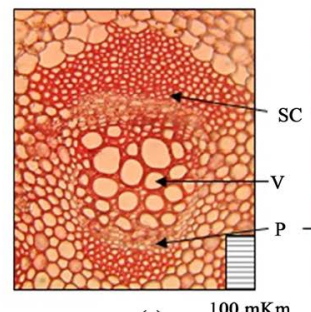

(e)

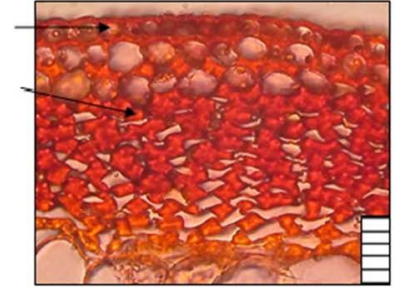

(b)

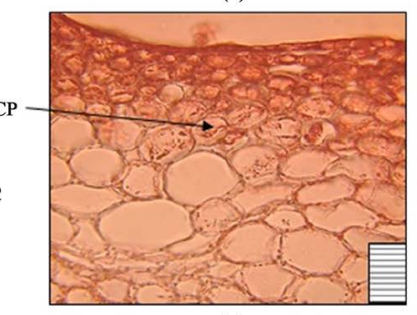

(c)

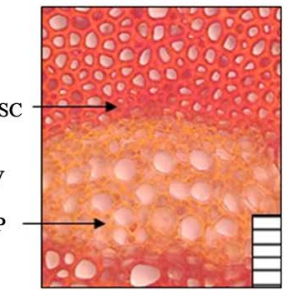

(f)

Figure 2. The structure of the stem of Silybum marianum: (a) detail of the overall appearance; (b) crustal parenchyma and collenchyme; in crustal parenchyma and chlorenchyma; (g) core; (d) bicollateral conductive beam; (e) sclerenchyma and phloem. Legend: HC hydrocytic cell, CL collenchyma, CP crustal parenchyma, CB conductive bundle, $\mathrm{C}$ core, $\mathrm{V}$ vessel, SC sclerenchyma, P phloem, E epidermi. 

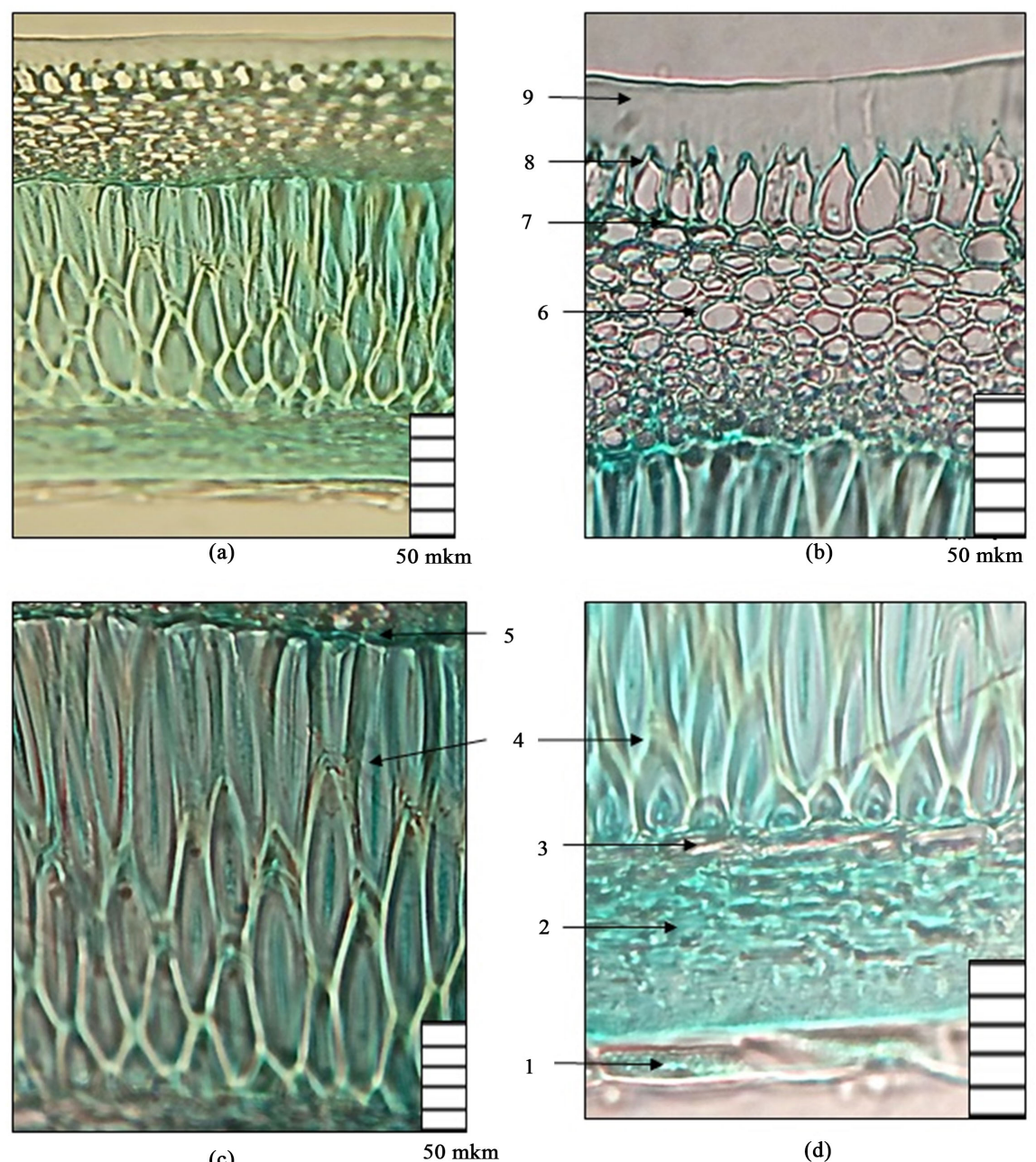

(c)

(d)

Figure 3. The structure of the fruit of Silybum marianum: (a) detail general view of the seed skin; (b) the shell of the fetus; in sclereides; g shell of the seed coat. 1 the rest of the endosperm, 2 the collapsed cells of the parenchyma of the seed coat, 3 the collapsed cells of the fetal parenchyma, 4 the sclereides, 5 collapsed cells of the endocarp, 6 fibrous cells of the mesocarp, 7 pigment layer, 8 elongated cells of the epidermis of the endocarp, 9 cuticle; 1 - 4 shells of the testa, 5 - 9 shells of the fetus.

Next, behind the layer of the endocarp, the seed coat is located, tightly fused with the pericarpium. It is represented by a thick layer of sclereids, having a flattened, elongated shape with thickened walls, pointed at both ends. The cavity of the sclereid has the form of a thin slit. Behind the layer of sclereid in the sheath of the bud is the parenchyma of collapsed fetal cells. The peel is adhered to the parenchyma of the inner part of the fetus and consists of several rows of parenchyma of collapsed cells of the seed coat that are soldered to the endosperm residue, consisting of one row of large cells with aleurone grains (Figure 3).

Thus, the structure of the anatomical structure of the vegetative and generative organs of $S$. marianum was studied, the structural features were revealed: mesomorphic leaf, dorsi-central mesophyll type characteristic of dicotyledonous plants; stem stem beam type. A comparative analysis of the anatomical structure 
showed that the seed coat has a general plan of the structure with other members of the family Asteraceae.

It is known that the Asteraceae family is characterized by a fruit-achene. On the anatomical section of $S$. marianum, there are clearly expressed membranes of the fetus (pericarp) and directly the sheath of the seed coat.

It is known that the seed peel is a diagnostic feature not only for morphological studies, but also for biochemical, since the seed coat is 95\% rich in biologically active substances-flavolignans.

\section{Conflicts of Interest}

The authors declare no conflicts of interest regarding the publication of this paper.

\section{References}

[1] Vvedensky, A.I. (1961) Flora of Uzbekistan. Vol. 5, Tashkent, 381-382.

[2] Prozina, M.N. (1960) Botanical Microtechnique. Izd. High School, Moscow, 206 p.

[3] Zakharevich, S.F. (1954) To the Method of Describing the Sheet Epidermis. Bulletin of Leningrad State University, No. 4, 65-75.

[4] Muradyan, L.G. (1987) Carpology-Anatomical Study of Some Members of the Genus Jurinea Cass (Asteraceae). Uchenye Zapiski, Yerevan, 107-112.

[5] Zhapakova, U.N. and Begbaeva, G.F. (1996) The Structure of the Fruits, Seeds and Leafy Organs of the Crustaceans Almost-Dentate-Senecio subdentatus LDB (This. Asteraceae). DAN RUz., Tashkent, 37-41.

[6] Kislichenko, V.S., Pospelov, S.V., Samorodov, V.N., Gudzenko, A.P., Terninko, I.I., Zamula, V.I., Bolokhovets, A.S., Nescheret, S.I. and Khanin, V.A. (2008) Milk Thistle-From Introduction to Use: Monograph. Poltava Writer, Poltava, 288. 